\title{
CONTENTS OF CLINICAL HEMORHEOLOGY, VOLUME 14, NUMBER 4
}

Liao Fu-long
D.E. McMillan
D.E. McMillan and J.I. Malone
Y. Missirlis and V. Kaleridis
S. Kawakami, Y. Isogai, J. Yamamoto,
T. Maeda, S. Ikemoto and M. Kaibara
Y. Mahler and S. Yedgar
Savish,
S. Barshtein, B. Gavis

T. Murata

M.W. Rampling and M.J. Pearson

S.M. MacRury, S.E. Lennie, K.R. Paterson, C.G. Semple and G.D.O. Lowe
Review Article

463 Treatment of blood stasis syndrome and hemorheology

\section{Conference Communications}

Proceedings of the First International and Eighth European Conference on Clinical Hemorheology Vienna, Austria, 5-8 July 1993 - Part V

Symposium: Diabetic Hemorheology

473 Blood viscosity and plasma proteins influencing it are increased in Type I diabetes in the DCCT

481 Hemorheological effects of intensive diabetes management in the DCCT

489 Polymorphonuclear leukocyte deformability in Type II diabetes mellitus and in ageing

Symposium: Red Cell Aggregation

497 Monitoring of red blood cell aggregability in a flow-chamber by computerized image analysis

509 Rheological study on erythrocyte aggregation with special reference to ESR - Application to quick estimation of ESR value -

519 Theoretical analysis of flow properties of aggregating red cell suspensions in narrow horizontal tubes

531 Enzymatic degradation of the red cell surface and its effect on Rouleaux formation

Non-Conference Communications Papers

539 Deformability of leucocyte subpopulations in Type I (insulin-dependent) and Type II (non-insulin-dependent) diabetic patients 
J.C. Ellory, S.J. Culliford, E.R. Horwitz, F.B.O. Mojiminiyi and J. Stuart

N. Uyesaka, S. Hasegawa, T. Nakamura, A.T. Hongo, A.N. Schechter and H. Shio

S. Hasegawa, T. Nomura, M. Iino, H. Shio, A.N. Schechter and N. Uyesaka

J. Uberos, A. Muñoz, A. Valenzuela, A. Molina, C. Ruiz and G. Galdó

O.K. Başkurt, M. Edremitlioğlu and A. Temiz

G. Caimi, R. Lo Presti, M. Montana, B. Canino and A. Sarno

M.R. Hardeman, P.T. Goedhart, J.G.G. Dobbe and K.P. Lettinga

M.R. Hardeman, P.T. Goedhart and N.H. Schut

E. Fukada
545

557

571

85
Rheological behaviour of neonatal blood at term
with or without polycythemia: A study in $0.38 \mathrm{~mm}$
diameter tubes

591 In vitro effects of in vivo activated leukocytes on $\mathrm{RBC}$ filterability and lipid peroxidation

Vascular atherosclerotic disease: Evaluation of white blood cell rheology and metabolism after acute intravenous administration of defibrotide

Laser-assisted optical rotational cell analyser (L.O.R.C.A.); I. A new instrument for measurement of various structural hemorheological parameters

Laser-assisted optical rotational cell analyser (L.O.R.C.A.); II. Red blood cell deformability: Elongation index versus cell transit time

\section{Book Review}

Reports on Progress in Polymer Physics in Japan

\section{Announcements}

Euroconference ETRO

635

IXth European Conference on Clinical

Haemorheology
Contents of Biorheology

Volume 31, Number 2 